\title{
DAPATKAH MODEL PENGUKURAN KINERJA ANGGOTA UNTUK ORGANISASI LABA DITERAPKAN PADA ORGANISASI NIRLABA?
}

\author{
Iwan Setyawan ${ }^{1 *}$, Aris Fatoni \\ ${ }^{(1,2)}$ Institut Bisnis dan Informatika (IBI) Kosgoro 1957 \\ *mr.setyawan510@gmail.com
}

\begin{abstract}
Abstrak.
Tujuan penelitian ini untuk menguji kesesuaianmodel pengukuran kinerja anggota organisasi nirlaba berdasarkan model pengukuran kinerja anggota organisasi laba. Metode survey digunakan untuk mendapatkan data primer melalui penyebaran kuesioner, dengan sampel meliputi anggota organisasi dan jama'ah yang dipilih dengan simple random sampling. Analisis data menggunakan structural equation modeling (SEM) Partial Least Squares Second Order Confirmatory dengan bantuan software Smart PLS 3.2. Hasil penelitian menemukan bahwa komitmen organisasi, dan pelatihan dapat diterapkan dalam mengukur kinerja anggota. Sementara, keterlibatan kerja tidak berpengaruh signifikan terhadap kinerja anggota. Secara lebih detil, dimensi countraproductivebehaviordari kerangka heuristik kinerja individual Koopmans et al. (2011) tidak cocok diterapkan untuk mengukur kinerja anggota pada organisasi nirlaba.
\end{abstract}

Kata kunci: Organisasi Nirlaba, Kinerja, Kualitas Pelayanan.

\begin{abstract}
.
The purpose of this study was to test the suitability of the performance measurement model for members of non-profit organizations based on the performance measurement model for members of the profit organization. The survey method was used to obtain primary data through distributing questionnaires, with the sample including members of the organization and congregation who were selected by simple random sampling technique. Data analysis used structural equation modeling (SEM) Partial Least Squares Second Order Confirmatory with the help of Smart PLS 3.2 software. The results of the study found that organizational commitment and training can be applied in measuring member's performance. Meanwhile, job involvement does not have a significant effect on member's performance. In more detail, the countraproductive behavior dimension of the individual performance heuristic framework Koopmans et al. (2011) is not suitable to be applied to measure the performance of members in non-profit organizations.
\end{abstract}

Keywords: Non-profit Organization, Performance, Service Quality..

\section{PENDAHULUAN}

Karyawan/anggota organisasi merupakan tulang punggung organisasi manapun dan memainkan peran penting dalam keberhasilan organisasi (Qaiser-Danish et al., 2015). Membuat karyawan/anggota organisasi dapat melakukan pekerjaan terbaiknya, bahkan dalam keadaan sulit, adalah salah satu tantangan yang paling sulit bagi para pimpinan organisasi (Messner, 2013).

Saat ini, organisasi terus menerus fokus pada peningkatan kinerja individu karyawan guna memperkaya kinerja organisasi (Thevanes \& Dirojan, 2018). Berbagai studi tentang kinerja karyawan/anggotaorganisasi telah dilakukan (Koopmans et al., 2011) yang bertujuan untuk mengeksplorasi variabel-variabel yang dapat meningkatkan kinerjanya. Elemen-elemen yang paling banyak menarik perhatian para peneliti diantaranya komitmen organisasi, keterlibatan kerja dan pelatihan.

Kebanyakan peneliti yang fokus pada isu tersebut meneliti pada organisasi laba dan publik (pemerintah). Padahal organisasi nirlaba juga memiliki peran yang sangat besar dalam memberikan solusi bagi permasalahan masyarakat yang belum tersentuh seluruhnya, baik oleh perusahaan atau pun instansi pemerintah. Oleh karena itu, tujuan dari penelitian ini adalah untuk mendalami apakah konsep komitmen organisasi, keterlibatan kerja, dan pelatihan dapat menjadi prediktor bagi kinerja pada organisasi nirlaba. Berikut ini beberapa hasil penelitian yang terkait dengan isu tersebut berikut dengan objek penelitiannya.

Tabel 1. Topik Riset dan Objek Penelitian 


\begin{tabular}{|c|c|c|}
\hline Peneliti & Judul & Tempat Penelitian \\
\hline $\begin{array}{l}\text { Sungu et al } \\
(2019)\end{array}$ & $\begin{array}{l}\text { How Does Organizational Commitment Relateto Job Performance? A } \\
\text { Conservation of ResourcePerspective }\end{array}$ & Organisasi laba \\
\hline Afroz (2018) & $\begin{array}{l}\text { Effects of Training on Employee Performance - A Study onBanking Sector, } \\
\text { Tangail Bangladesh }\end{array}$ & Organisasi laba \\
\hline $\begin{array}{l}\text { Odero \& Makori } \\
\text { (2018) }\end{array}$ & $\begin{array}{l}\text { Employee Involvement AndEmployee Performance: The CaseOf Part Time } \\
\text { Lecturers In PublicUniversities In Kenya }\end{array}$ & Organisasi Publik \\
\hline Thevanes \& & Impact of Training and Job Involvement on Job & Organisasi laba \\
\hline Dirojan (2018) & Performance & \\
\hline $\begin{array}{l}\text { Widjajaniet al. } \\
\text { (2017) }\end{array}$ & $\begin{array}{l}\text { The effect of Trust, Job Involvement, Organizational Commitment, } \\
\text { Knowledge Sharing Behavior to Employee Performance }\end{array}$ & Organisasi laba \\
\hline $\begin{array}{l}\text { Al-Mzary et al. } \\
(2015)\end{array}$ & $\begin{array}{l}\text { Training and its Impact on the Performance of Employees at Jordanian } \\
\text { Universities from the Perspective of Employees: The Case of Yarmouk } \\
\text { University }\end{array}$ & Organisasi publik \\
\hline $\begin{array}{l}\text { Thohirohet al. } \\
\text { (2015) }\end{array}$ & $\begin{array}{l}\text { The Development of Organizational Commitment Scale for Non- } \\
\text { profitOrganization }\end{array}$ & Organisasi nirlaba \\
\hline Khan (2011) & $\begin{array}{l}\text { Job Involvement as Predictor of Employee Commitment: Evidence from } \\
\text { Pakistan }\end{array}$ & $\begin{array}{l}\text { Organisasi laba \& } \\
\text { Organisasi publik }\end{array}$ \\
\hline $\begin{array}{l}\text { Koopmans et al. } \\
\text { (2011) }\end{array}$ & Conceptual Frameworks of Individual Work Performance & Organisasi laba \\
\hline
\end{tabular}

Sumber: Diolah dari berbagai sumber

Anggota organisasi yang baru memasuki organisasi, memiliki tujuan dan nilai berbeda yang ingin mereka puaskan melalui pekerjaannya. Semakin tinggi tingkat kesesuaian persepsi anggota organisasi antara nilai-nilai dan keyakinannya dengan organisasi, semakin kuat kecenderungannya untuk berkomitmen pada organisasi (Ghosh \& Swamy, 2014).Meyer \& Allen, (1979) dalam (Colquitt et al., 2019)memaknai komitmen organisasi sebagai keinginan dari pihak anggota organisasi untuk tetap bertahan menjadi anggota organisasi.

Minat organisasi untuk memiliki anggota organisasi yang berkomitmen seperti itu telah meningkat karena ada perbedaan besar antara kinerja anggota yang berkomitmen dan anggota lainnya. Anggota organisasi yang berkomitmen memiliki kinerja yang baik dalam organisasi dan membantu organisasi untuk tumbuh dan menghadapi lingkungan yang kompetitif (Adnan et al., 2018).

Berbagai bukti empiris terkait hubungan antara kedua variabel tersebut telah menghasilkan temuan yang beragam. Hasil studi dari (Kaplan \& Kaplan, 2018) menemukan bahwa komitmen organisasi yang meliputi dimensi komitmen afektif memiliki dampak yang signifikan dan positif pada kinerja, tetapi dimensi komitmen normatif dan komitmen kontinu tidak berpengaruh signifikan terhadap kinerja. Sementara temuan dari (Nurandini \& Lataruva, 2014)menyimpulkan bahwa baik, komitmen afektif, komitmen normatif dan komitmen kontinyu memiliki pengaruh positif dan signifikan terhadap kinerja karyawan. Berdasarkan temuan-temuan tersebut, dapat diambil suatu hipotesis:

\section{$\mathrm{H}_{1}$ : Komitmen organisasi mempengaruhi kinerja anggota organisasi.}

Di samping komitmen organisasi, tingkat keterlibatan anggota organisasi dalam pekerjaannya juga merupakan ukuran kinerja pekerjaannya (Kasaya \& Munjuri, 2018). Sethi \& Mittal (2016) mendefinisikan keterlebatan kerja sebagai sejauh mana anggota organisasi mencurahkan secara total baik, kemampuan, pikiran, waktu bahkan menganggap pekerjaannya tersebut sebagai bagian dari kehidupannya. Sejumlah peneliti telah melakukan studi mengenai pengaruh dari keterlibatan kerja pada kinerja karyawan, misalnya (Aleinein, 2016). Dia menemukan bahwa terdapat pengaruh yang signifikan dari keterlibatan kerja yang direfleksikan oleh cognitive job involvement dan behavioral job involvement terhadap job performance, sementara emotional job involvement tidak berpengaruh terhadap job performance.

Kakinsale et al. (2015), Riza et al. (2017), Odero \& Makori (2018), Gusmarni \& Kasmiruddin (2018), serta Rizwan et al. (2011) menemukan bahwa keterlibatan kerja memberikan pengaruh positif terhadap kinerja karyawan. Dari temuan-temuan tersebut, dapat diambil suatu hipotesis:

$\mathbf{H}_{2}$ :Keterlibatan kerja mempengaruhi kinerja anggotaorganisasi.

Setelah mendorong dari aspek psikologi, organisasi juga harus meningkatkan skill anggota 
Seminar Nasional Penelitian dan Pengabdian kepada Masyarakat Universitas Sang Bumi Ruwa Jurai Tahun 2020

organisasinya. Dalam konteks ini, pelatihan dianggap sebagai praktik SDM yang krusial untuk meningkatkan kinerja karyawan melalui peningkatan kompetensi, sikap dan perilaku anggota organisasi (Thevanes \& Dirojan, 2018). Beberapa bukti empiris yang mendukung bahwa pemberian pelatihan mempengaruhi kinerja anggota organisasi diantaranya (Afroz, 2018),(Sugiarti et al., 2016), (Yusnita \& Fadhil, 2015) dan (Al-Mzary et al., 2015). Dari temuan-temuan tersebut dapat ditarik sebuah hipotesis:

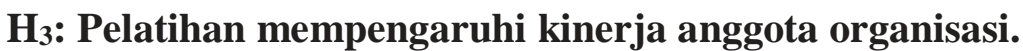

Tiga buah konsep stimulus terhadap kinerja anggota organisasi telah diuraikan dan dibuktikan secara empiris oleh peneliti-peneliti sebelumnya. Bagaimana ukuran dari anggota organisasi yang meningkat kinerjanya atau tidak? Terdapat beragam pendapat mengenai pengukuran kinerja ini, tergantung pada aspek dan perspektif mana kinerja anggota tersebut akan diukur. Dalam penelitian ini mengadopsi kerangka kerja heuristik dari (Koopmans et al., 2011) untuk mengukur kinerja anggota organisasi. Kerangka kerja tersebut meliputi task performance, contextual performance, adaptive performance dan countraproductive behavior.

\section{METODE PENELITIAN}

Penelitian ini menggunakan pendekatan kuantitatif, dengan survey sebagai metodenya. Populasi dalam penelitian ini meliputi anggota organisasi dari Majelis Taqorrub Ilallah (MTI) yang pernah mengikuti program pelatihan dan gathering dan jama'ah yang tersebar di 3 kecamatan di Kabupaten Bekasi, yaitu Setu, Tambun dan Cibitung.

Populasi dalam penelitian ini meliputi anggota dan jama'ah MTI. Jumlah populasi dari anggota MTI yang sudah mendapatkan pelatihan dan kegiatan gathering sebanyak 137 anggota.Untuk menentukan jumlah sampel anggota menggunakan rumus Slovin, yaitu:

Dimana :

$$
n=\frac{N}{\left(1+N e^{2}\right)}
$$

n adalah banyaknya sampel

$\mathrm{N}$ adalah jumlah populasi

$e$ adalah toleransi error $(5 \%)$

Berdasarkan rumus Slovin tersebut, diperoleh jumlah sampel sebanyak 99,6 responden atau dibulatkan 100 responden, sedangkan untuk menentukan jumlah sampel jama'ah, karena populasi jumlahnya tidak diketahui, maka peneliti menggunakan dasar rule of thumb Roscoe (1975) dalam (Sekaran \& Bougie, 2016) dalam menentukan sampelnya, dan menetapkan sampel sebanyak 100 responden. Selanjutnya sampel dipilih dengan menggunakan teknik acak sederhana.

\section{Variabel Penelitian dan Operasionalisasi Variabel}

Variabel yang diteliti dalam penelitian ini terdiri dari variabel eksogen yang meliputi komitmen organisasi $\left(\mathrm{X}_{1}\right)$, keterlibatan kerja $\left(\mathrm{X}_{2}\right)$, dan pelatihan $\left(\mathrm{X}_{3}\right)$, variabel endogen yaitu kinerja anggota (Y) Untuk operasionalisasi variabel secara rinci disajikan dalam Tabel 2 yang meliputi variabel, definisi variabel, dimensi dan instrumen. Seluruh indikator diukur dengan skala semantic differencial.

Tabel 2. Operasionalisasi Variabel

\begin{tabular}{|c|c|c|c|c|}
\hline \multirow{2}{*}{\begin{tabular}{l}
\multicolumn{1}{c}{ Variabel } \\
Komitmen \\
Organisasi \\
$\left(X_{1}\right)$
\end{tabular}} & \multicolumn{2}{|c|}{ Definisi Variabel } & Dimensi & Instrument \\
\hline & \multicolumn{2}{|c|}{$\begin{array}{lr}\text { Komitmen } & \\
\text { organisasi } & \text { adalah } \\
\text { sejauh } & \text { mana } \\
\text { anggota } & \text { MTI } \\
\text { bersedia } & \text { tetap } \\
\text { bertahan } & \text { dalam }\end{array}$} & 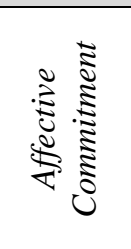 & $\begin{array}{l}\text { - Merasa sejalan dengan nilai-nilai organisasi }\left(\mathrm{X}_{1.1}\right) \\
\text { - Senang bergabung dengan organisasi }\left(\mathrm{X}_{1.2}\right) \\
\text { - Tujuan organisasi sejalan dengan tujuan pribadi }\left(\mathrm{X}_{1.3}\right) \\
\text { - Keinginan untuk mewujudkan tujuan organisasi }\left(\mathrm{X}_{1.4}\right) \\
\text { - Memiliki ikatan emosional dengan organisasi }\left(\mathrm{X}_{1.5}\right)\end{array}$ \\
\hline
\end{tabular}




\begin{tabular}{|c|c|c|c|}
\hline Variabel & Definisi Variabel & Dimensi & Instrument \\
\hline & $\begin{array}{l}\text { organisasi baik } \\
\text { karena alasan } \\
\text { emosional, } \\
\text { pertimbangan } \\
\text { benefit and cost, } \\
\text { maupun alasan } \\
\text { normatif. } \\
\text { (Meyer dan Allen, } \\
\text { 1990) }\end{array}$ & 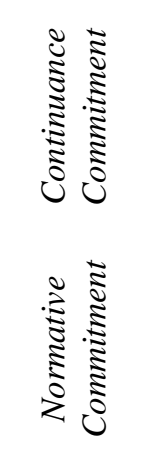 & $\begin{array}{l}\text { - Sifat kekeluargaan yang baik }\left(\mathrm{X}_{1.6}\right) \\
\text { - Suasana saling mendukung antar anggota }\left(\mathrm{X}_{1.7}\right) \\
\text { - Menambah pengetahuan }\left(\mathrm{X}_{1.8}\right) \\
\text { - Merasa rugi jika meninggalkan organisasi }\left(\mathrm{X}_{1.9}\right) \\
\text { - Infaq dianggap sebagai investasi akhirat }\left(\mathrm{X}_{1.10}\right) \\
\text { - Anggota organisasi sudah banyak membantu }\left(\mathrm{X}_{1.11}\right) \\
\text { - Merasa berhutang budi pada organisasi }\left(\mathrm{X}_{1.12}\right) \\
\text { - Sudah menjadi kewajiban pribadi untuk bergabung } \\
\text { - Sudah sepantasnya tetap bergabung }\left(\mathrm{X}_{1.14}\right)\end{array}$ \\
\hline \multirow[t]{2}{*}{$\begin{array}{l}\text { Keterlibatan } \\
\text { Kerja }\left(\mathbf{X}_{2}\right)\end{array}$} & $\begin{array}{l}\text { Keterlibatan kerja } \\
\text { adalah sejauh mana } \\
\text { keterlibatan } \\
\text { anggota } \\
\text { organisasidengan } \\
\text { pekerjaannya, yang } \\
\text { ditunjukkan dengan } \\
\text { kecintaannya, } \\
\text { keaktifannya dan } \\
\text { upaya ekstra yang } \\
\text { dilakukannya. } \\
\text { (Yoshimura, 1996) }\end{array}$ & 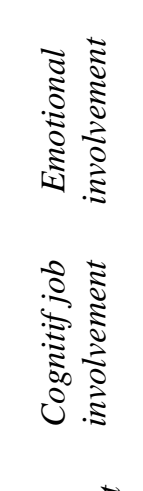 & $\begin{array}{l}\text { - Job attachment }\left(\mathrm{X}_{2.1}\right) \\
\text { - Job interest }\left(\mathrm{X}_{2.2}\right) \\
\text { - } \text { Job satisfaction }\left(\mathrm{X}_{2.3}\right) \\
\text { - } \text { Berpartisipasi aktif }\left(\mathrm{X}_{2.4}\right) \\
\text { - Pekerjaan sebagai minat utama kehidupan }\left(\mathrm{X}_{2.5}\right) \\
\text { - Keadaan psikologis }\left(\mathrm{X}_{2.6}\right) \\
\text { - Self-esteem }\left(\mathrm{X}_{2.7}\right)\end{array}$ \\
\hline & & 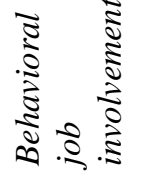 & $\begin{array}{l}\text { - Bekerja dengan ekstra }\left(\mathrm{X}_{2.8}\right) \\
\text { - Voluntary learning }\left(\mathrm{X}_{2.9}\right) \\
\text { - Behavioral intention }\left(\mathrm{X}_{2.10}\right)\end{array}$ \\
\hline $\begin{array}{l}\text { Pelatihan } \\
\left(\mathbf{X}_{\mathbf{3}}\right)\end{array}$ & $\begin{array}{l}\text { Pelatihan adalah } \\
\text { sejauh mana } \\
\text { anggota organisasi } \\
\text { menerapkan ilmu } \\
\text { yang diperolehnya } \\
\text { dalam pelatihan di } \\
\text { dalam organisasi. } \\
\text { (Kirkpatrick, \& } \\
\text { Kirkpatrick, 2016) }\end{array}$ & 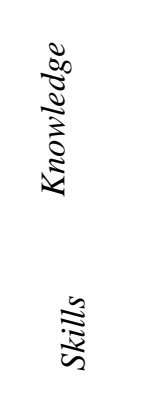 & $\begin{array}{l}\text { - Menerapkan perencanaan }\left(\mathrm{X}_{3.1}\right) \\
\text { - Menerapkan pengorganisasian sumber daya }\left(\mathrm{X}_{3.2}\right) \\
\text { - Melakukan action }\left(\mathrm{X}_{3.3}\right) \\
\text { - Menerapkan pengendalian }\left(\mathrm{X}_{3.4}\right) \\
\text { - Menyusun rencana kegiatan }\left(\mathrm{X}_{3.5}\right) \\
\text { - Mengelola sumber daya }\left(\mathrm{X}_{3.6}\right) \\
\text { - Melaksanakan kegiatan }\left(\mathrm{X}_{3.7}\right) \\
\text { - Mengontrol kegiatan }\left(\mathrm{X}_{3.8}\right)\end{array}$ \\
\hline \multirow[b]{2}{*}{$\begin{array}{l}\text { Kinerja } \\
\text { Anggota (Y) }\end{array}$} & & 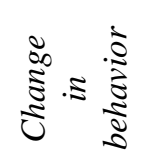 & $\begin{array}{l}\text { - Lebiih teliti dalam merencanakan sesuatu }\left(\mathrm{X}_{3.9}\right) \\
\text { - Tidak menganggap mudah pekerjaan }\left(\mathrm{X}_{3.10}\right) \\
\text { - Lebih semangat dalam berorganisasi }\left(\mathrm{X}_{3.11}\right)\end{array}$ \\
\hline & 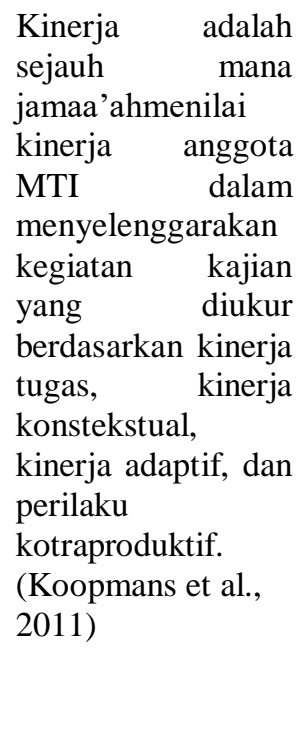 & $\frac{0}{\frac{0}{5}}$ & $\begin{array}{l}\text { - Kemampuan menyusun rencana }\left(\mathrm{Y}_{1}\right) \\
\text { - Kemampuan mengelola pekerjaan }\left(\mathrm{Y}_{2}\right) \\
\text { - Berorientasi pada hasil }\left(\mathrm{Y}_{3}\right) \\
\text { - Penentuan pioritas pekerjaan }\left(\mathrm{Y}_{4}\right) \\
\text { - Kemampuan memanfaatkan waktu }\left(\mathrm{Y}_{5}\right) \\
\text { - Komitmen yang kuat }\left(\mathrm{Y}_{6}\right) \\
\text { - Beranggung jawab }\left(\mathrm{Y}_{7}\right) \\
\text { - Kemampuan berkolaborasi dalam tim }\left(\mathrm{Y}_{8}\right) \\
\text { - Kreatif }\left(\mathrm{Y}_{9}\right) \\
\text { - Inisiatif }\left(\mathrm{Y}_{10}\right) \\
\text { - Menerima kritikan }\left(\mathrm{Y}_{11}\right) \\
\text { - Peduli akan kualitas }\left(\mathrm{Y}_{12}\right) \\
\text { - Fleksibel dalam bekerja }\left(\mathrm{Y}_{13}\right) \\
\text { - Bersikap tenang dalam situasi sulit }\left(\mathrm{Y}_{14}\right) \\
\text { - Mampu cepat beradaptasi dengan pekerjaan }\left(\mathrm{Y}_{15}\right)\end{array}$ \\
\hline
\end{tabular}


Seminar Nasional Penelitian dan Pengabdian kepada Masyarakat Universitas Sang Bumi Ruwa Jurai Tahun 2020

\begin{tabular}{|c|c|c|c|}
\hline Variabel & Definisi Variabel & Dimensi & Instrument \\
\hline & & 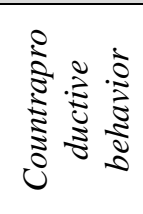 & $\begin{array}{l}\text { - } \text { Malas dalam bekerja }\left(\mathrm{Y}_{16}\right) \\
\text { - Suka mengeluh }\left(\mathrm{Y}_{17}\right) \\
\text { - Kerja asal-asalan }\left(\mathrm{Y}_{18}\right) \\
\text { - Tidak peduli akan kualitas }\left(\mathrm{Y}_{19}\right) \\
\text { - Sering konflik }\left(\mathrm{Y}_{20}\right)\end{array}$ \\
\hline
\end{tabular}

Sumber: Diolah dari berbagai sumber

\section{Analisis Data}

Data yang sudah terkumpul selanjutnya dianalisis dengan menggunakan analisis structural equation modeling (SEM) Partial Least Squares second order confirmatory. Analisis dilakukan secara dua tingkat, pertama menguji hubungan antar variabel latin dan tingkat kedua menguji hubungan indikator dengan variabel latennya (Gatignon, 2014).Selanjutnya dilakukan analisa model struktural dan uji hipotesis.

\section{HASIL}

\section{HASIL DAN PEMBAHASAN}

\section{Analisa Model Pengukuran}

Analisa model pengukuran (outer model)dilakukan untuk memastikan bahwa instrumen sebagai alat ukur, mampu merefleksikan atau membentuk konstruknya secara valid dan reliabel. Suatu indikator dikatakan valid, bila memiliki nilai loading factor $\geq 0,7$, sedangkan suatu variabel dikatakan reliabel, bila variabel tersebut mempunyai nilai composite reliability $>0,7$, nilai Average Variance Extraced (AVE) > 0,5 dan nilai cronbach alpha> 0,6 (Wati, 2018). Di samping itu, dibuktikan secara statistik bahwa nilai t-statistik, baik untuk indikator maupun dimensi lebih besar dari 1,65 untuk $\alpha=0,05$ one tailed test(Hair et al., 2017)

Setelah melalui proses analisa dan pengujian secara statistik dalam outer model, terdapat 5 indikator yang harus di-drop, dikarenakan tidak memenuhi persyaratan di atas. Indikator-indikator tersebut adalah $\mathrm{X}_{1.11}, \mathrm{Y}_{11}, \mathrm{Y}_{12}, \mathrm{Y}_{16}$, dan $\mathrm{Y}_{20}$. Setelah dilakukan proses analisa data kembali dengan sebelumnya mengeluarkan kelima indikator tersebut hasilnya masih ada dua indikator lagi yang memiliki loading factor di bawah 0,7, yaitu item $\mathrm{Y}_{10}$ dan $\mathrm{Y}_{19}$. Pada proses analisa ketiga, semua item sudah memiliki loading factor di atas 0,7 kemudian dilakukan resampling bootstrapping, untuk keperluan uji hipotesis. Pada Tabel 3 disajikan komponen pengukuran validitas dan reliabilitas serta koefisien parameter, $\mathrm{t}$-statistik dan $p$-value.

Meskipun demikian, ketika dilakukan uji statistik dengan membandingkan antara t-statistik dengan t-tabel (1,65), terdapat empat indikator yang memiliki nilai t-statistik $<1,65$. Keempat indikator tersebut adalah $\mathrm{Y}_{13}$, dan $\mathrm{Y}_{14}$ pada dimensi adaptive performance sertaY $\mathrm{Y}_{17}$ dan $\mathrm{Y}_{18}$ pada dimensi countraproductive behavior pada variabel kinerja anggota. Dengan demikian, maka dimensi countraproductive behavior tidak dapat merefleksikan variabel kinerja anggota dalam model penelitian ini.

Tabel 3.Ukuran Validitas, Reliabilitas dan Hipotesis

\begin{tabular}{|c|c|c|c|c|c|c|c|c|c|c|}
\hline \multirow[b]{2}{*}{$\begin{array}{c}\text { Kons } \\
\text { truk }\end{array}$} & \multirow[b]{2}{*}{$\underset{\text { si }}{\text { Dimen }}$} & \multirow[b]{2}{*}{$\begin{array}{l}\text { Koef. } \\
\text { Para } \\
\text { meter }\end{array}$} & \multirow[b]{2}{*}{$\begin{array}{c}T- \\
\text { Statistik }\end{array}$} & \multirow[b]{2}{*}{$\begin{array}{c}P \text { - } \\
\text { Value }\end{array}$} & \multicolumn{3}{|c|}{ Reliability } & \multicolumn{2}{|c|}{ Validity } & \multirow[b]{2}{*}{$\begin{array}{c}T- \\
\text { Statistik }\end{array}$} \\
\hline & & & & & $C A$ & CR & $A V E$ & $\begin{array}{l}\text { Indik } \\
\text { ator }\end{array}$ & $\begin{array}{c}\text { Outer } \\
\text { Loading }\end{array}$ & \\
\hline \multicolumn{5}{|c|}{ Komitmen Organisasi } & 0,928 & 0,939 & 0,529 & & & \\
\hline \multirow{5}{*}{\multicolumn{2}{|c|}{ 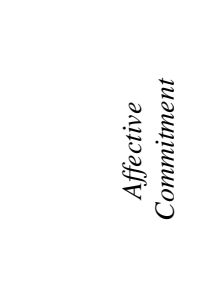 }} & \multirow{5}{*}{0,934} & \multirow{5}{*}{57,743} & \multirow{5}{*}{0,000} & \multirow{5}{*}{0,883} & \multirow{5}{*}{0,915} & \multirow{5}{*}{0,685} & $\mathrm{X}_{1.1}$ & 0709 & 8,033 \\
\hline & & & & & & & & $\mathrm{X}_{1.2}$ & 0,866 & 25,200 \\
\hline & & & & & & & & $\mathrm{X}_{1.3}$ & 0,873 & 24,370 \\
\hline & & & & & & & & $\mathrm{X}_{1.4}$ & 0,897 & 36,115 \\
\hline & & & & & & & & $\mathrm{X}_{1.5}$ & 0,776 & 14,574 \\
\hline
\end{tabular}




\begin{tabular}{|c|c|c|c|c|c|c|c|c|c|c|}
\hline \multirow{10}{*}{$\begin{array}{l}\text { Kons } \\
\text { truk }\end{array}$} & \multirow[b]{2}{*}{$\begin{array}{l}\text { Dimen } \\
\text { si }\end{array}$} & \multirow[b]{2}{*}{$\begin{array}{l}\text { Koef. } \\
\text { Para } \\
\text { meter }\end{array}$} & \multirow[b]{2}{*}{$\begin{array}{c}T- \\
\text { Statistik }\end{array}$} & \multirow[b]{2}{*}{$\begin{array}{c}P- \\
\text { Value }\end{array}$} & \multicolumn{3}{|c|}{ Reliability } & \multicolumn{2}{|c|}{ Validity } & \multirow[b]{2}{*}{$\begin{array}{c}T- \\
\text { Statistik }\end{array}$} \\
\hline & & & & & $C A$ & $C R$ & $A V E$ & $\begin{array}{l}\text { Indik } \\
\text { ator }\end{array}$ & $\begin{array}{c}\text { Outer } \\
\text { Loading }\end{array}$ & \\
\hline & \multirow{5}{*}{ 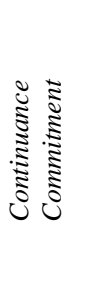 } & \multirow{5}{*}{0,893} & \multirow{5}{*}{36,729} & \multirow{5}{*}{0,000} & \multirow{5}{*}{0,901} & \multirow{5}{*}{0,926} & \multirow{5}{*}{0,716} & $\mathrm{X}_{1.6}$ & 0,822 & 17,897 \\
\hline & & & & & & & & $\mathrm{X}_{1.7}$ & 0,820 & 20,113 \\
\hline & & & & & & & & $\mathrm{X}_{1.8}$ & 0,872 & 21,002 \\
\hline & & & & & & & & $\mathrm{X}_{1.9}$ & 0,890 & 36,243 \\
\hline & & & & & & & & $\mathrm{X}_{1.10}$ & 0,826 & 20,778 \\
\hline & \multirow{3}{*}{ 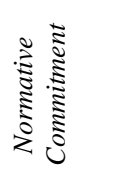 } & \multirow{3}{*}{0,812} & \multirow{3}{*}{18,864} & \multirow{3}{*}{0,000} & \multirow{3}{*}{0,819} & \multirow{3}{*}{0,893} & \multirow{3}{*}{0,738} & $\mathrm{X}_{1.12}$ & 0,740 & 10,548 \\
\hline & & & & & & & & $\mathrm{X}_{1.13}$ & 0,930 & 61,880 \\
\hline & & & & & & & & $\mathrm{X}_{1.14}$ & 0,895 & 31,742 \\
\hline Keterli & atan Kerj & & & & 0,928 & 0,939 & 0,562 & & & \\
\hline & & & & & & & & $\mathrm{X}_{2.1}$ & 0,875 & 27,831 \\
\hline & 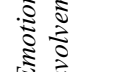 & 0,877 & 34,903 & 0,000 & 0,845 & 0,907 & 0,766 & $\mathrm{X}_{2.2}$ & 0,930 & 50,466 \\
\hline & & & & & & & & $\mathrm{X}_{2.3}$ & 0,816 & 19,924 \\
\hline & $\cong$ & & & & & & & $\mathrm{X}_{2.4}$ & 0,867 & 27,666 \\
\hline & 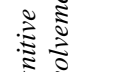 & 0,931 & 53,443 & 0,000 & 0,887 & 0,922 & 0,748 & $\mathrm{X}_{2.5}$ & 0,872 & 27,441 \\
\hline & $\mathrm{e}^{50} \stackrel{े}{\Xi}$ & & & & & & & $\mathrm{X}_{2.6}$ & 0,897 & 31,004 \\
\hline & & & & & & & & $\mathrm{X}_{2.7}$ & 0,822 & 17,098 \\
\hline & 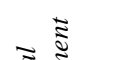 & & & & & & & $\mathrm{X}_{2.8}$ & 0,830 & 25,786 \\
\hline & 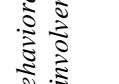 & 0,830 & 18,757 & 0,000 & 0,694 & 0,829 & 0,619 & $\mathrm{X}_{2.9}$ & 0,763 & 9,999 \\
\hline & $\stackrel{0}{2}$ & & & & & & & $\mathrm{X}_{2.10}$ & 0,765 & 12,325 \\
\hline Pelatih & & & & & $\mathbf{0 , 9 3 0}$ & 0,941 & 0,592 & & & \\
\hline & & & & & & & & $\mathrm{X}_{3.1}$ & 0,821 & 19,917 \\
\hline & $\stackrel{8}{3}$ & 0,930 & 53,086 & 0,000 & 0,894 & 0,927 & 0,760 & $\mathrm{X}_{3.2}$ & 0,900 & 44,161 \\
\hline & $\begin{array}{l}\text { ఏे } \\
\vdots\end{array}$ & 0,930 & 53,086 & 0,000 & 0,894 & 0,927 & $0, / 60$ & $\mathrm{X}_{3.3}$ & 0,907 & 44,769 \\
\hline & & & & & & & & $\mathrm{X}_{3.4}$ & 0,858 & 25,480 \\
\hline & & & & & & & & $\mathrm{X}_{3.5}$ & 0,782 & 13,074 \\
\hline & $\cong$ & 0.938 & 63.005 & 0.000 & 0.821 & 0.882 & 0.651 & $\mathrm{X}_{3.6}$ & 0,839 & 25,203 \\
\hline & $\frac{\pi}{n}$ & 0,938 & 03,005 & 0,000 & 0,821 & 0,882 & 0,651 & $\mathrm{X}_{3.7}$ & 0,788 & 15,599 \\
\hline & & & & & & & & $\mathrm{X}_{3.8}$ & 0,816 & 17,755 \\
\hline & $\approx=$ & & & & & & & $\mathrm{X}_{3.9}$ & 0,808 & 18,468 \\
\hline & 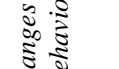 & 0,873 & 31,518 & 0,000 & 0,781 & 0,873 & 0,696 & $\mathrm{X}_{3.10}$ & 0,861 & 25,389 \\
\hline & $\tilde{0}$ & & & & & & & $\mathrm{X}_{3.11}$ & 0,833 & 20,893 \\
\hline Kinerja & Anggota & & & & 0,850 & 0,860 & 0,295 & & & \\
\hline & & & & & & & & $\mathrm{Y}_{1}$ & 0,746 & 12,896 \\
\hline & $\begin{array}{r}\breve{\Xi} \\
+\end{array}$ & & & & & & & $\mathrm{Y}_{2}$ & 0,874 & 36,297 \\
\hline & ) & 0,924 & 33,705 & 0,000 & 0,878 & 0,911 & 0,673 & $\mathrm{Y}_{3}$ & 0,873 & 34,995 \\
\hline & $\frac{8}{5}$ & & & & & & & $\mathrm{Y}_{4}$ & 0,809 & 19,531 \\
\hline & & & & & & & & $\mathrm{Y}_{5}$ & 0,795 & 12,866 \\
\hline & & & & & & & & $\mathrm{Y}_{6}$ & 0,752 & 13,211 \\
\hline & 忥 & 0878 & 27003 & 0000 & 0814 & 0877 & 0642 & $\mathrm{Y}_{7}$ & 0,799 & 13,907 \\
\hline & $\stackrel{0}{0}$ & $0,8 / 8$ & 27,093 & 0,000 & 0,814 & $0,8 / 1 /$ & 0,642 & $\mathrm{Y}_{8}$ & 0,820 & 16,405 \\
\hline & & & & & & & & $\mathrm{Y}_{9}$ & 0,831 & 18,265 \\
\hline
\end{tabular}


Seminar Nasional Penelitian dan Pengabdian kepada Masyarakat Universitas Sang Bumi Ruwa Jurai Tahun 2020

\begin{tabular}{|c|c|c|c|c|c|c|c|c|c|c|}
\hline \multirow[b]{2}{*}{$\begin{array}{c}\text { Kons } \\
\text { truk }\end{array}$} & \multirow[b]{2}{*}{$\begin{array}{c}\text { Dimen } \\
\text { si }\end{array}$} & \multirow[b]{2}{*}{$\begin{array}{l}\text { Koef. } \\
\text { Para } \\
\text { meter }\end{array}$} & \multirow[b]{2}{*}{$\begin{array}{c}T- \\
\text { Statistik }\end{array}$} & \multirow[b]{2}{*}{$\begin{array}{c}P- \\
\text { Value }\end{array}$} & \multicolumn{3}{|c|}{ Reliability } & \multicolumn{2}{|c|}{ Validity } & \multirow[b]{2}{*}{$\begin{array}{c}T- \\
\text { Statistik }\end{array}$} \\
\hline & & & & & $C A$ & $C R$ & $A V E$ & $\begin{array}{c}\text { Indik } \\
\text { ator }\end{array}$ & $\begin{array}{c}\text { Outer } \\
\text { Loading }\end{array}$ & \\
\hline & \multirow{3}{*}{ 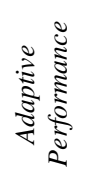 } & \multirow{3}{*}{0,313} & \multirow{3}{*}{2,026} & \multirow{3}{*}{0,022} & \multirow{3}{*}{0,811} & \multirow{3}{*}{0,884} & \multirow{3}{*}{0,718} & $\mathrm{Y}_{13}$ & 0,820 & 1,571 \\
\hline & & & & & & & & $\mathrm{Y}_{14}$ & 0,826 & 1,713 \\
\hline & & & & & & & & $\mathrm{Y}_{15}$ & 0,894 & 1,953 \\
\hline & \multirow{2}{*}{ 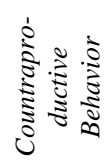 } & \multirow[b]{2}{*}{0,205} & \multirow[b]{2}{*}{1,117} & \multirow[b]{2}{*}{0,120} & \multirow[b]{2}{*}{0,768} & \multirow[b]{2}{*}{0,883} & \multirow[b]{2}{*}{0,791} & $Y_{17}$ & 0,965 & 1,635 \\
\hline & & & & & & & & $\mathrm{Y}_{18}$ & 0,807 & 1,211 \\
\hline
\end{tabular}

Sumber: Hasil data diolah (2020)

Pada pengujian reliabilitas, semua dimensi memiliki nilai Composite Reliability $(C R)>0,7$, Cronbach Alpha $(C A)>0,6$ dan nilai Average Variance Extracred (AVE) > 0,5. Artinya semua dimensi mampu mengukur dan merefleksikan variabel masing-masing. Namun demikian, pada uji statistik, dimensi countraproductive behavior pada variabel kinerja anggota memiliki t-statistik < 1,65. Dengan demikian, maka dimensi tersebut tidak dapat merefleksikan variabel kinerja anggota.

\section{Analisa Model Struktural}

Terdapat tiga jenis ukuran yang dilakukan dalam menganalisa model struktural(inner model) untuk mengevaluasi spesifikasi struktur model, ukuran pengaruh yang dikonstribusikan dan relevansi model dalam memprediksi, yaitu:

Pengujian pertama dengan melihat nilai koefisien determinasi $\left(\mathrm{R}^{2}\right)$ untuk melihat kontribusi yang diberikan oleh variabel-variabel laten pada kinerja anggota dan kualitas pelayanan.

Tabel 4. R-Square

\begin{tabular}{cc}
\hline Variabel & R Square \\
Kinerja Anggota (Y) & 0,594 \\
\hline Sumber: Data diolah (2020) &
\end{tabular}

Nilai $\mathrm{R}^{2}$ untuk variabel kinerja anggota $\left(\mathrm{R}_{1}^{2}\right)$ sebesar 0,594 menunjukkan bahwa variabel kinerja anggota dapat dijelaskan oleh variabel komitmen organisasi, keterlibatan kerja, dan pelatihan sebesar 59,4\%, sedangkan sisanya dipengaruhi oleh variabel lain yang tidak ada dalam model.

Pengujian kedua dengan menggunakan perhitungan predictive relevance $\left(\mathrm{Q}^{2}\right)$ untuk melihat kemampuan relevansi model dalam memprediksi. Perhitungan $Q^{2}$ adalah:

$$
\begin{aligned}
& Q^{2}=1-\left(1-R^{2}\right) \\
& Q^{2}=1-(1-0,594) \\
& Q^{2}=1-0,406=0,594
\end{aligned}
$$

Hasil perhitungan menunjukkan nilai $Q^{2}$ sebesar 0,594 artinya model yang dibangun oleh komitmen organisasi, keterlibatan kerja, dan pelatihan, mampu menjelaskan atau memprediksi kinerja anggota organisasi sebesar 59,4\%. Nilai $Q^{2}>0$ menunjukkan bahwa model memiliki predictive relevance yang baik (Ghozali dalam Wati, 2018).

Pengujian ketiga, dilakukan dengan menggunakan Goodness of Fit Index (GoF) untuk memvalidasi kinerja gabungan antara model pengukuran dan model struktural. Rumus evaluasi GoF sebagai berikut:

$$
G o F=\sqrt{\overline{A V E} x \overline{R^{2}}}
$$

Dimana $\overline{A V E}$ adalah rata-rata AVE dari semua variabel(lihat Tabel 2) dan $\overline{R^{2}}$ adalah rata-rata dari koefisien determinasi untuk variabel kinerja anggota dan kualitas pelayanan.Dengan demikian maka:

$$
\begin{aligned}
& \text { GoF }=\sqrt{0,495 \times 0,594} \\
& \text { GoF }=\sqrt{0,272}=0,52
\end{aligned}
$$


Nilai Goodness of Fit Index (GoF) sebesar 0,52 artinya model termasuk ke dalam kategori besar. Berdasarkan hasil perhitungan $R^{2}, Q^{2}$ dan GoFmenunjukkan bahwa model sudah memenuhi semua kriteria dan dapat melakukan langkah selanjutnya untuk pengujian hipotesis model struktural.

Sebagai dasar acuan dalam pengujian model struktural pada Tabel 5disajikan nilai koefisien parameter, t-hitung, dan p-value dari outputanalisis bootstrapping dengan one-tailed test.

Tabel 5 Path Coefficients dan Specific Indirect Effects

\begin{tabular}{|c|c|c|c|c|c|}
\hline $\begin{array}{l}\text { Hipo- } \\
\text { tesis }\end{array}$ & Variabel & $\begin{array}{l}\text { Koefisien } \\
\text { Parameter }\end{array}$ & $\begin{array}{c}\text { T } \\
\text { Hitung }\end{array}$ & $\begin{array}{c}P \\
\text { Value }\end{array}$ & Keterangan \\
\hline $\mathrm{H}_{1}$ & Komitmen Organisasi $\rightarrow$ Kinerja Anggota & 0,208 & 2,081 & 0,019 & Signifikan \\
\hline $\mathrm{H}_{2}$ & Keterlibatan Kerja $\rightarrow$ Kinerja Anggota & 0,121 & 1,164 & 0,123 & $\begin{array}{c}\text { Tidak } \\
\text { Signifikan }\end{array}$ \\
\hline $\mathrm{H}_{3}$ & Pelatihan $\rightarrow$ Kinerja Anggota & 0,989 & 10,444 & 0,000 & Signifikan \\
\hline
\end{tabular}

\section{Pengaruh Komitmen Organisasi terhadap Kinerja Anggota MTI \\ Hipotesis Penelitian 1:}

$\mathrm{H}_{0}$ : Tidak terdapat pengaruh positif dan signifikan antara Komitmen Organisasi terhadapKinerja Anggota Majelis Taqorrub Ilallah (MTI).

$\mathrm{H}_{1}$ : Terdapat pengaruh positif dan signifikan antara Komitmen Organisasi terhadap Kinerja Anggota Majelis Taqorrub Ilallah (MTI).

Tabel 5 menunjukkan bahwa nilai t-statistik untuk uji hipotesis pertama iniadalah 2,081 yang lebih besar dari t-tabel $(2,081>1,65)$. Tingkat signifikansi menunjukkanp-value $(0,019)<0,05$. Keputusan untuk hipotesis penelitian pertama ini, adalah menolak hipotesi nol $\left(\mathrm{H}_{0}\right)$. Hal ini berarti bahwa komitmen organisasi secara positif dan signifikan mempengaruhi kinerja anggota Majelis Taqorrub Ilallah (MTI).

\section{Pengaruh Keterlibatan Kerja terhadap Kinerja Anggota MTI \\ Hipotesis Penelitian 2:}

$\mathrm{H}_{0}$ : Tidak terdapat pengaruh positif dan signifikan antara Keterlibatan Kerja terhadap Kinerja Anggota Majelis Taqorrub Ilallah (MTI).

$\mathrm{H}_{1}$ : Terdapat pengaruh positif dan signifikan antara Keterlibatan Kerja terhadap Kinerja Anggota Majelis Taqorrub Ilallah (MTI).

Nilai t-statistik untuk pengujian hipotesis keduaadalah 1,164. Nilai ini lebih kecil dari t-tabel $(1,164<1,65)$. Taraf signifikansi p-value $(0,123)>0,05$. Keputusan dari hipotesis kedua adalah menerima hipotesis nol $\left(\mathrm{H}_{0}\right)$. Artinya bahwa keterlibatan kerja tidak memberikan pengaruh positif dan signifikan terhadap kinerja anggota Majelis Taqorrub Ilallah.

\section{Pengaruh Pelatihan terhadap Kinerja Anggota MTI}

\section{Hipotesis Penelitian 3}

$\mathrm{H}_{0}$ : Tidak terdapat pengaruh positif dan signifikan antara Pelatihan terhadap Kinerja Anggota Majelis Taqorrub Ilallah (MTI).

$\mathrm{H}_{1}$ : Terdapat pengaruh positif dan signifikan antara Pelatihan terhadap Kinerja Anggota Majelis Taqorrub Ilallah (MTI).

Nilai t-statistik untuk pengujian hipotesis ini adalah 10,444. Nilai tersebut lebih besar dari 1,65 atau $(10,444>1,65)$. P-value sebesar 0,000, yang berarti lebih kecil dari 0,05. Keputusan untuk hipotesis ketiga adalah menolak hipotesis nol $\left(\mathrm{H}_{0}\right)$. Hal ini berarti terdapat pengaruh positif dan signifikan antara pelatihan terhadap kinerja anggota MTI.

\section{Intepretasi Model}

Berdasarkan koefisien-koefisien parameter jalur yang diperoleh pada Tabel 5, maka secara matematis model struktural dalam penelitian ini adalah sebagai berikut:

$$
K A=0,208 K O+0,989 P+e
$$

Persamaan

\section{Keterangan:}

$$
\begin{aligned}
& \mathrm{KA}=\text { Kinerja Anggota } \\
& \mathrm{KO}=\text { Komitmen Organisasi } \\
& \mathrm{P}=\text { Pelatihan }
\end{aligned}
$$


Pada model persamaan penelitian, Komitmen Organisasi mempunyai koefisien regresi sebesar 0,208 artinya, ketika Komitmen Organisasi meningkat (bertambah 1), maka Kinerja Anggota akan naik sebesar 0,208. Pelatihan dengan koefisien regresi sebesar 0,989artinya bahwa setiap ada peningkatan knowledge, skills, dan change in behaviorsebagai hasil dari pelatihan sebanyak satu point, maka akan meningkatkan kinerja anggota sebesar 0,989 point.

\section{PEMBAHASAN}

Pada pengujian outer model, disimpulkan bahwa dimensi countraproductive behavior bukan merupakan model yang baik dalam merefleksikan kinerja anggota. Countraproductive behaviordalam penelitian ini merupakan perilaku negatif yang dicerminkan oleh anggota organisasi, seperti malas-malasan dalam melaksanakan tugas, suka mengeluh, kerja asal-asalan dan tidak peduli akan kualitas. Perilaku seperti ini, sering ditemui di dalam organisasi laba ketika karyawannya merasakan adanya ketidakadilan di dalam organisasi (Krischer et al., 2010).

Perilaku negatif ini tidak signifikan pada organisasi nirlaba, khususnya MTI yang bergerak di bidang keagamaan. Hal ini disebabkan oleh beberapa hal, pertama, bergabungnya anggota ke dalam organisasi didasari oleh niat lillahi ta'ala secara sukarela dan bahkan mereka merasa bertanggung jawab untuk bergabung dengan organisasi dalam menangkal pengaruh negatif dan melindungi generasi dari gerakan demoralisasi. Hasil riset ini juga menemukan bahwa anggota memiliki kedekatan secara emosional yang tinggi dengan organisasi, bahkan keterlibatan yang tinggi dalam menjalankan tugas pun justru membuat mereka secara emosional semakin mendekatkan dirinya pada organisainya.

Jadi perilaku kontrapoduktif bukan merupakan perilaku yang ditunjukkan oleh anggota organisasi MTI. Oleh karena itu, maka perilaku kontra produktif tidak merefleksikan kinerja anggota organisasi nirlaba, khususnya MTI.

\section{Pengaruh Komitmen Organisasi terhadap Kinerja Anggota MTI}

Hasil uji hipotesis pertama menunjukkan, terdapat pengaruh positif dan signifikan antara komitmen organisasi dengan kinerja anggota. Komitmen organisasi itu sendiri secara signifikan direfleksikan oleh dimensi komitmen afektif, komitmen kontinyu, dan komitmen normatif. Dari ketiga dimensi tersebut, yang memberikan kontribusi terbesar terhadap komitmen organisasi adalah dimensi komitmen afektif dengan koefisien parameter sebesar 0,934 (lihat Tabel 3). Koefisien parameter sebesar tersebut menunjukkan bahwa anggota MTI memiliki kedekatan emosional yang sangat erat dengan organisasinya.

Komitmen afektif merupakan aset yang paling berharga bagi organisasi. Dengan komitmen afektif yang tinggi, maka anggota MTI secara emosional menjadi sangat dekat dengan organisasi dan secara pribadi mereka merasa bertanggung jawabatas tingkat kesuksesan organisasi (Meyer dan Allen (1984) dalam(Weibo et al., 2010). Oleh karena itu, organisasi harus mampu menjaga dan memelihara kondisi ini agar komitmen anggota terhadap organisasi tetap konsisten tinggi. Jika kondisi tersebut bisa dipertahankan, maka komitmen yang tinggi pada organisasi dapat digunakan untuk memprediksi perilaku organisasi di masa depan seperti keluar dari organisasi, keterlambatan, hipotiroidisme, dan tidak adanya sumber daya manusia yang efektif, yang pada akhirnya memberikan dampak yang signifikan terhadap produktivitas sumber daya manusia(Dabir \& Azarpira, 2017).

Temuan ini mendukung dan memperkuat temuan-temuan sebelumnya, diantaranya temuan (Nurandini \& Lataruva, 2014)yang meneliti pada karyawan Perumnas Jakarta, (Adiftiya, 2014) yang meneliti pada karyawan di sebuah perusahaan kontraktor pertambangan, (Sutanto \& Ratna, 2015)yang meneliti pada karyawan di sebuah perusahaan swasta, dan (Sapitri, 2016)yang meneliti karyawan di perusahaan BUMN di Riau menghasilkan temuan yang sama bahwa komitmen afektif, komitmen kontinyu, dan komitmen normatif memiliki pengaruh yang positif terhadap kinerja karyawan.

Dari temuan tersebut menyuratkan bahwa jenis organisasi apa pun membutuhkan anggota organisasi yang memiliki kedekatan psikologis dengan organisasinya. Terlebih kondisi persaingan yang ketat dan kondisi ekonomi melemah seperti sekarang ini, keberadaan anggota organisasi yang memiliki komitmen yang tinggi dapat membantu organisasi keluar dari kesulitan.

Pengaruh Keterlibatan Kerja terhadap Kinerja Anggota MTI 
Hasil pengujian hipotesis kedua menunjukkan bahwa keterlibatan kerja tidak memberikan pengaruh positif dan signifikan terhadap kinerja anggota Majelis Taqorrub Ilallah. Konsep keterlibatan kerja hampir mirip dengan komitmen organisasi, namun konstruknya berbeda. Dalam keterlibatan kerja, lebih erat terkait dengan identifikasi dengan aktivitas kerja langsung seseorang, sedangkan komitmen organisasi mengacu pada keterikatan seseorang dengan organisasi (Brown (1996) dalam Birdie \& Jain, 2016). Hal ini berarti, meskipun keterikatan anggota MTI terhadap organisasi tinggi, tetapi tidak menjamin bahwa keterikatan dengan aktivitas pekerjaan atau tugastugasnya tinggi juga.

Temuan ini bertentangan dengan hasil penelitian sebelumnya, seperti temuan (Kakinsale et al., 2015)yang meneliti karyawan pada perusahaan minuman, (Riza et al., 2017)yang meneliti pada karyawan di sebuah pusat perbelanjaaan, (Gusmarni \& Kasmiruddin, 2018)yang meneliti pada karyawan di sebuah RSIA, dan temuan dari (Rizwan et al., 2011) yang meneliti pada karyawan RSUD menghasilkan temuan yang sama yaitu kinerja karyawan dipengaruhi secara signifikan oleh keterlibatan kerja.

Pada temuan-temuan penelitian sebelumnya menunjukkan bahwa kinerja anggota/karyawan pada organisasi laba dan instansi pemerintah dipengaruhi secara positif oleh keterlibatan kerja, tetapi pada organisasi nirlaba (dalam penelitian ini) justru sebaliknya. Sehingga dapat ditarik suatu kesimpulan bahwa pengaruh keterlibatan kerja pada kinerja anggota/karyawan menunjukkan ada perbedaan implikasi, antara organisasi laba dan publik dengan organisasi nirlaba.

\section{Pengaruh Pelatihan terhadap Kinerja Anggota MTI}

Hasil uji hipotesis ketiga, menyimpulkan bahwa kinerja anggota dipengaruhi secara positif dan signifikan oleh pelatihan. Konteks pelatihan dalam penelitian ini direfleksikan secara signifikan oleh pengetahuan, keterampilan, dan perilaku. Dimensi keterampilan (skills) memberikan kontribusi terbesar bagi variabel pelatihan dengan koefisien parameter sebesar 0,938. Keterampilan yang dimaksud meliputi keterampilan dalam menyusun rencana kegiatan, mengelola sumber daya, melaksanakan kegiatan, dan mengontrol kegiatan. Dimensi ini yang memberikan pengaruh terbesar dalam peningkatan kinerja anggota MTI.

Bahkan pelatihan menjadi prediktor terbesar dalam koefisien regresi dalam peningkatan kinerja anggota (lihat persamaan 1).Dengan demikian dapat dikatakan bahwa pelatihan merupakan elemen terpenting dalam meningkatkan kinerja anggota organisasi.

Temuan penelitian ini memperkuat temuan-temuan sebelumnya diantaranya temuan Hanafiah \& Juhadi (2020) yang meneliti pada RS Bersalin,Hartomo \& Luturlaen, (2020) yang meneliti karyawan di perusahaan BUMN, Sugiarti et al.(2016) yang meneliti karyawan pada perusahaan swasta, Yusnita \& Fadhil, (2015) yang meneliti karyawan Developer, Dahmiri \& Sakta, (2014) yang meneliti pegawai Dinas Pendidikan, dan Triasmoko \& Mukzam, (2014) yang meneliti karyawan di perusahaan BUMN. Riset mereka menemukan hasil yang sama dan konsisten bahwa pelatihan berpengaruh positif dan signifikan terhadap kinerja karyawan.

Temuan-temuan tersebut mengarah pada sebuah kesimpulan bahwa perilaku kerja dapat berubah setelah anggota organisasi/karyawan mengikuti program pelatihan, baik yang diselenggarakan oleh organisasi laba, instansi pemerintah atau pun organisasi nirlaba.

\section{KESIMPULAN}

Konsep pengukuran elemen kinerja anggota pada organisasi nirlaba memiliki persamaan dan perbedaan dengan organisasi laba atau organisasi publik. Persamaannya yaitu, variabel komitmen organisasi dan pelatihan, baik pada orgnisasi laba, organisasi publik maupun organisasi nirlaba samasama memberikan pengaruh pada kinerja anggota/karyawan. Perbedaannya terletak, pertama pada dimensi yang merefleksikan kinerja. Pada organisasi laba, dimensi perilaku kontraproduktif merefleksikan variabel kinerja anggota, tetapi pada organisasi nirlaba sebaliknya. Kedua, variabel keterlibatan kerja berpengaruh terhadap kinerja anggota pada organisasi laba atau organisasi publik tetapi tidak pada organisasi nirlaba.

\section{UCAPAN TERIMAKASIH}

Terima kasih tak terhingga peneliti ucapkan kepada Direktorat Riset dan Pengabdian kepada 
Seminar Nasional Penelitian dan Pengabdian kepada Masyarakat

Universitas Sang Bumi Ruwa Jurai Tahun 2020

Masyarakat, Dirjen Penguatan Riset dan Pengembangan Kemenristek Dikti Republik Indonesia yang telah sepenuhnya mendanai dan memfasilitasi penelitian ini.

\section{DAFTAR PUSTAKA}

Adiftiya, J. (2014). Pengaruh Komitmen Organisasi Terhadap Kinerja Karyawan Pada PT. Bukit Makmur Mandiri Utama Site Kideco Jaya Agung Batu Kajang Kabupaten Paser. Ilmu Administrasi Bisnis, 2(4), 833-845.

Adnan, S., Nhaily, A., \& Wang, H. (2018). “"To Evaluate and Study the relationship between employees" commitment and individual performance".

Afroz, N. N. (2018). Effects of Training on Employee Performance : A Study on Banking Sector, Tangail Bangladesh. Global Journal of Economic and Business, 4(1), 111-124.

Al-Mzary, M. M. M., Al-rifai, A. D. ., \& Al-Momany, M. O. E. (2015). Training and its impact on the performance of employees at Jordanian universities from the perspective of employees : The case of Yarmouk University. Journal of Education and Practice, 6(32), 128-140.

Aleinein, A. A. (2016). The Impact of Job involvement on Job Performance at UNRWA Gaza Field Office. In The Islamic University-Gaza Research.

Birdie, A., \& Jain, M. (2016). Organizational Behavior and Virtual Work: Concepts and Analytical Approaches. In Canada: Apple Academic Press, Inc.

Colquitt, J. A., LePine, J. A., \& Wesson, M. J. (2019). ORGANIZATIONAL BEHAVIOR: Improving Performance and Commitment in the Workplace, 6Th Edition. In New York: McGraw-Hill Education.

Dabir, A. R., \& Azarpira, M. (2017). Organizational Commitment and Its Impact on Employee Behavior. International Journal of Human Capital Urban Manage, 2(1), 49-56.

Dahmiri, \& Sakta, K. (2014). Pengaruh Pelatihan Terhadap Kinerja Pegawai Dinas Pendidikan Kabupaten Sarolangun. Mankeu, 3(1), 374-380.

Gatignon, H. (2014). Statistical analysis of management data: Third edition. In New York: Springer.

Ghosh, S., \& Swamy, D. R. (2014). A Literature Review on Organizational Commitment - A Comprehensive Summary. Journal of Engineering Research and Applications, 4(12), 4-14.

Gusmarni, \& Kasmiruddin. (2018). Pengaruh Keterlibatan Kerja dan Komitmen Organisasi Terhadap Kinerja Karyawan Pada Rumah Sakit Ibu dan Anak Milano Teluk Kuantan. JOM FISIP, 5(2), $1-10$.

Hair, J. F., Hult, G. T. M., Ringle, C. M., \& Sarstedt, M. (2017). A Primer on Partial Least Squares Structural Equation Modeling (PLS-SEM). Second Edition. In California: Sage.

Hanafiah, \& Juhadi. (2020). Pengaruh Pelatihan dan Pengalaman Kerja Terhadap Kinerja Karyawan di Rumah Sakit Bersalin Kota Bandung. Jurnal Ilmiah MEA (Manajemen, Ekonomi, Dan Akuntansi), 4(1), 333-349. https://doi.org/10.24176/bmaj.v3i1.4435

Hartomo, N. K., \& Luturlaen, B. S. (2020). Pengaruh Pelatihan Terhadap Kinerja Karyawan Kantor Pusat PT. Pos Indonesia (Persero) Bandung. Jurnal Ilmiah Manajemen, Ekonomi Dan Akuntansi, 4(1), 200-207.

Kakinsale, A., Tumbel, A. L., \& Sendow, G. M. (2015). Pengaruh Keterlibatan Kerja, Lingkungan Kerja, dan Kompensasi Terhadap Kinerja Karyawan Pada PT. Bangun Wenang Beverages Manado. Jurnal EMA, 3(1), 900-911.

Kaplan, M., \& Kaplan, A. (2018). The Relationship between Organizational Commitment and Work Performance: a Case of Industrial Enterprises. Journal of Economic and Social Development (JESD), 5(1), 46-50.

Kasaya, M. ., \& Munjuri, M. . (2018). Effect of Employee Involvement on Job Performance At the Kenya Medical Research Institute (Centre for Global Health Research) Kisumu. International Journal of Economics, Commerce and Management, VI(5), 826-847.

Koopmans, L., Bernaards, C. M., Hildebrandt, V. H., Schaufeli, W. B., De Vet Henrica, C. W., \& Van Der Beek, A. J. (2011). Conceptual frameworks of individual work performance: A systematic review. In Journal of Occupational and Environmental Medicine (Vol. 53, Issue 8). American College of Occupational and Environmental Medicine. 
Krischer, M. M., Penney, L. M., \& Hunter, E. M. (2010). Counterproductive Work Behavior: Can It Sometimes Be Good to Be Bad? Journal of Occupational Health Psychology, 15(2), 154-166.

Messner, W. (2013). Effect of organizational culture on employee commitment in the Indian IT services sourcing industry. Journal of Indian Business Research, 5(2), 76-100.

Nurandini, A., \& Lataruva, E. (2014). Analisis Pengaruh Komitmen Organisasi Terhadap Kinerja Karyawan (Studi Pada Pegawai Perum Perumnas Jakarta). Jurnal Studi Manajemen \& Organisasi, 11(1), 78-91.

Odero, J. A., \& Makori, E. (2018). Employee Involvement and Employee Performance : the Case of Part Time Lecturers in Public Universities in Kenya. International Journal of Management and Commerce Innovations, 5(2), 1169-1178.

Qaiser-Danish, R., Aslam, N., \& Yasir-Ali, H. (2015). Relationship Between JOB Performance, JOB Involvement and Career Salience of Employees in Education Sector of Pakistan. American Journal of Educational Research, 1(2), 19-23.

Riza, F. A., Prohimi, A. H. A., \& Juariyah, L. (2017). Pengaruh Kompensasi dan Keterlibatan Kerja tehadap Kinerja Karyawan. Jurnal EKOBIS-Ekonomi Dan Bisnis, 22(22), 58-66.

Rizwan, M., Khan, D. J., \& Saboor, F. (2011). Relationship of Job involvement with Employee Performance: Moderating role of Attitude. European Journal of Business and Management, 3(8), 77-86.

Sapitri, R. (2016). Pengaruh Komitmen Organisasi Terhadap Kinerja Karyawan Perusahaan Listrik Negara Area Pekanbaru. JOM FISIP, 3(2), 1-9.

Sekaran, U., \& Bougie, R. (2016). Research Methods for Business: A Skill-Building Approach, 7th Edition. In West Sussex,: John Wiley \& Son Ltd.

Sethi, A., \& Mittal, K. (2016). A study of job involvement among senior secondary school teachers. International Journal of Applied Research, 2(2), 205-209.

Sugiarti, Hartati, T., \& Amir, H. (2016). Pengaruh Pelatihan Kerja Terhadap Kinerja Karyawan Pada PT Padma Ardya Aktuaria Jakarta. Jurnal Epigram Vol. 13 No. 1 April, 13(1), 13-20.

Sutanto, E. M., \& Ratna, A. (2015). Pengaruh Komitmen Organisasional Terhadap Kinerja Karyawan Berdasarkan Karakteristik Individual. Bisma-Jurnal Bisnis Dan Manajemen, 9(1), 56-70.

Thevanes, N., \& Dirojan, T. (2018). The Impact Of Training and Development on Job Performance. International Journal of Scientific and Management Research, 1(1), 1-10.

Triasmoko, D., \& Mukzam, M. D. (2014). Penelitian pada Karyawan PT Pos Indonesia (Persero) Cabang Kota Kediri. Jurnal Administrasi Bisnis, 12(1), 1-10.

Wati, Lela Nurlaela. 2018. Metodologi Penelitian Terapan. Aplikasi SPSS, EVIEWS, Smart PLS dan AMOS, (Edisi Kedua). Bekasi: CV. Pustaka Amri.

Weibo, Z., Kaur, S., \& Jun, W. (2010). New development of organizational commitment: A critical review (1960 - 2009). African Journal of Business Management, 4(1), 012-020.

Yoshimura, A. (1996). A Review and Proposal of Job Involvement. Keio Business Review, 33, 175184.

Yusnita, N., \& Fadhil, F. (2015). Pengaruh Pelatihan Karyawan Terhadap Kinerja Karyawan Pada CV Cibalung Happy Land Bogor. JIMFE (Jurnal Ilmiah Manajemen Fakultas Ekonomi), 1(1), $1-5$. 